\title{
KEMAMPUAN SISWA MENERAPKAN KERJA ILMIAH PADA TOPIK CIRI-CIRI MAKHLUK HIDUP MELALUI PENDEKATAN KETERAMPILAN PROSES DI SMP NEGERI 14 PONTIANAK
}

\author{
Oleh: Reni Marlina ${ }^{1}$
}

\begin{abstract}
Abstrak
Penelitian ini berjudul "Kemampuan Siswa Menerapkan Kerja Ilmiah pada Topik Ciri-ciri Makhluk Hidup melalui Pendekatan Keterampilan Proses di Kelas VII SMP Negeri 14 Pontianak". Penelitian ini bertujuan untuk mengetahui kemampuan siswa menerapkan kerja ilmiah pada topik ciri-ciri makhluk hidup melalui pendekatan keterampilan proses di kelas VII SMP Negeri 14 Pontianak. Penelitian ini merupakan eksperimen semu (Quasy Eksperimen) dengan rancangan pre-test and pos-test one group design. Subjek dalam penelitian ini adalah siswa kelas VII B SMP Negeri 14 Pontianak tahun ajaran 2006/2007 yang sedang mempelajari topik ciri-ciri makhluk hidup. Objek dalam penelitian ini adalah penerapan kerja ilmiah melalui pendekatan keterampilan proses. Alat pengumpul data berupa tes kemampuan siswa yang berbentuk esai terdiri dari 10 butir soal. Soal tersebut divalidasi oleh 3 orang validator, hasilnya valid dan setelah diuji reliabilitasnya diperoleh 0,4995 tergolong sedang. Dari hasil analisis data diperoleh informasi bahwa kemampuan siswa dalam menerapkan kerja ilmiah pada topik ciri-ciri makhluk hidup melalui pendekatan keterampilan proses tergolong cukup $(66,47 \%)$. Dari perhitungan uji wilcoxon diperoleh $Z_{\text {hitung }}$ (4.92) $>Z_{\text {tabel }}$ (1.64) maka dapat disimpulkan bahwa penerapan kerja ilmiah pada topik ciri-ciri makhluk hidup melalui pendekatan keterampilan proses berpengaruh terhadap kemampuan siswa di kelas VII B SMP Negeri 14 pontianak.
\end{abstract}

Kata kunci: Kerja Ilmiah, Pendekatan Keterampilan Proses.

\section{PENDAHULUAN}

Kurikulum Berbasis Kompetensi (KBK) maupun pada kerangka berpikir pengembangan silabus Kurikulum Tingkat Satuan Pendidikan

\footnotetext{
${ }^{I}$ Reni Marlina adalah Dosen Program Studi Pend. Biologi FKIP Untan
} 
(KTSP) menjelaskan bahwa pengetahuan yang diperoleh siswa merupakan pengetahuan ilmiah. Pengetahuan ilmiah yang dimaksud disini adalah pengetahuan yang telah mengalami uji kebenaran melalui kerja ilmiah (Depdiknas, 2006: 4). Namun, pada kenyataannya belum dilaksanakan oleh guru dalam pembelajaran di kelas. Hal ini berdasarkan wawancara dengan guru bidang studi IPA Biologi kelas VII SMP Negeri 14 Pontianak (2 Desember 2006), kecenderungan pembelajaran IPA Biologi saat ini adalah siswa hanya mempelajarinya sebagai produk, menghapalkan konsep dan teori. Hal ini belum sesuai dengan tuntutan Kurikulum Tingkat Satuan Pendidikan (KTSP) yang mengutamakan pembelajaran IPA Biologi pada empat unsur utama yaitu sikap ilmiah, proses ilmiah, produk ilmiah dan aplikasinya (Depdiknas, 2006: 4-5). Berdasarkan survei terhadap dua orang guru yang mengajar IPA Biologi di kelas VII SMP Negeri 14 Pontianak (6-7 Desember 2006), diketahui bahwa metode yang biasa digunakan adalah ceramah dan pemberian tugas. Hal tersebut belum dapat memenuhi tuntutan Kurikulum Tingkat Satuan Pendidikan (KTSP) yang menekankan proses pembelajaran pada pemberian pengalaman langsung (Depdiknas, 2006: 4). Sehingga dalam penelitian ini peneliti menggunakan pendekatan keterampilan proses untuk menyampaikan topik ciri-ciri makhluk hidup.

Pada topik ciri-ciri makhluk hidup kompetensi dasar yang akan dicapai oleh siswa adalah mampu mengidentifikasi ciri-ciri makhluk hidup, yang dalam pembelajarannya dapat diterapkan dengan kerja ilmiah melalui pendekatan keterampilan proses. Selain itu, ciri-ciri makhluk hidup merupakan topik yang akan diajarkan setelah kerja ilmiah sehingga diharapkan dapat membantu siswa mengingat kembali tentang urutan kerja ilmiah yang telah dipelajarinya. Dengan menerapkan kerja ilmiah melalui pendekatan keterampilan proses, siswa dapat menggunakan keterampilan mengamati, mengklasifikasikan maupun mengkomunikasikan ciri-ciri makhluk hidup. Penerapan kerja ilmiah pada topik ciri-ciri makhluk hidup melalui pendekatan keterampilan proses mengharapkan siswa untuk dapat bekerja secara ilmiah mulai dari menemukan masalah, melakukan pengamatan, membentuk hipotesis, merancang percobaan dan menarik suatu kesimpulan. Dengan demikian, hasil pengkajian topik ciri-ciri makhluk hidup ini memungkinkan untuk mengukur kemampuan kerja ilmiah siswa.

Berdasarkan uraian di atas, peneliti tertarik untuk meneliti dan memilih menerapkan kerja ilmiah pada topik ciri-ciri makhluk hidup melalui pendekatan keterampilan proses di kelas VII SMP Negeri 14 Pontianak. Dipilihnya SMP Negeri 14 Pontianak, karena sekolah tersebut 
merupakan tempat peneliti mengadakan PPL II sehingga peneliti telah mengetahui kondisi siswa dan kegiatan belajar mengajar di SMP Negeri 14 Pontianak. Dengan demikian, akan mempermudah dalam pengambilan data.

\section{METODE}

Penelitian ini dilakukan untuk mengetahui kemampuan siswa menerapkan kerja ilmiah pada topik ciri-ciri makhluk hidup melalui pendekatan keterampilan proses di kelas VII SMP Negeri 14 Pontianak. Sebelum pengajaran, siswa terlebih dahulu diberikan soal-soal pre-test untuk mengetahui kemampuan awal siswa.

Bentuk penelitian yang dipandang cocok untuk mengetahui kemampuan siswa menerapkan kerja ilmiah pada topik ciri-ciri makhluk hidup melalui pendekatan keterampilan proses di kelas VII SMP Negeri 14 Pontianak adalah penelitian semu (quasy eksperimen). Bentuk penelitian ini digunakan karena objek penelitian adalah siswa sehingga tidak mungkin untuk membuat kondisi objek dalam satu kelas sama.

Penelitian ini bertujuan untuk mengetahui kemampuan siswa menerapkan kerja ilmiah pada topik ciri-ciri makhluk hidup melalui pendekatan keterampilan proses di kelas VII SMP Negeri 14 Pontianak, dengan menggunakan model rancangan eksperimen semu yaitu Pre-test and Post-test One Group Design (Arikunto, 1998: 79). Pengaruh penerapan kerja ilmiah melalui pendekatan keterampilan proses terhadap kemampuan siswa kelas VII SMP Negeri 14 Pontianak dapat dilihat dari hasil tes siswa kelas VII SMP Negeri 14 Pontianak.

Penelitian dilakukan di kelas VII SMP Negeri 14 Pontianak tahun ajaran 2006/ 2007 yang terdiri dari lima kelas yaitu kelas VII A, VII B, VII C, VII D dan VII E. Kelima kelas tersebut dilakukan cabut undi untuk menentukan kelas yang menjadi subjek penelitian. Setelah dilakukan cabut undi, yang menjadi subjek penelitian adalah kelas VII B tahun ajaran 2006/2007. Objek dalam penelitian ini adalah penerapan kerja ilmiah melalui pendekatan keterampilan proses.

\section{HASIL DAN PEMBAHASAN}

Kemampuan seluruh siswa dalam menerapkan kerja ilmiah pada topik ciri-ciri makhluk hidup melalui pendekatan keterampilan proses dapat dilihat pada lampiran 6 diperoleh tabel 4.1. Urutan nama siswa pada tabel 4.1 dibuat berdasarkan urutan absen. Pada tabel 4.1 diketahui bahwa rata-rata kemampuan seluruh siswa dalam menerapkan kerja ilmiah pada topik ciri-ciri makhluk hidup melalui pendekatan 
keterampilan proses sebesar $\mathbf{6 6 , 4 7 \%}$ dengan kategori cukup. Persentase kemampuan seluruh siswa dalam menerapkan kerja ilmiah pada topik ciri-ciri makhluk hidup melalui pendekatan keterampilan proses yang paling tinggi adalah $\mathbf{8 5 , 7 1 \%}$ dengan kategori Baik. Sedangkan persentase kemampuan seluruh siswa dalam menerapkan kerja ilmiah pada topik ciri-ciri makhluk hidup melalui pendekatan keterampilan proses yang paling rendah adalah $\mathbf{4 2 , 8 6 \%}$ dengan kategori kurang sekali.

Tabel 1 Persentase Kemampuan Siswa Menerapkan Tahapan Kerja Ilmiah Melalui Pendekatan Keterampilan Proses

\begin{tabular}{|c|l|c|c|}
\hline No & Tahapan Kerja Ilmiah & $\begin{array}{c}\text { Rata-rata Kemampuan } \\
\text { Siswa (\%) }\end{array}$ & $\begin{array}{c}\text { Kategori } \\
\text { Kemampuan }\end{array}$ \\
\hline 1 & Merancang Percobaan & 76,85 & Cukup \\
\hline 2 & Penulisan Cara Kerja & 72,22 & Cukup \\
\hline 3 & Penulisan Hasil Percobaan & 88,89 & Sangat Baik \\
\hline 4 & Penulisan Pembahasan & 49,44 & Kurang Sekali \\
\hline 5 & $\begin{array}{l}\text { Penulisan Hasil } \\
\text { Kesimpulan }\end{array}$ & 69,44 & Cukup \\
\hline
\end{tabular}

Tabel di atas merupakan tabel kemampuan siswa dalam menerapkan tahapan kerja ilmiah melalui pendekatan keterampilan proses. Dari tabel di atas diketahui bahwa kemampuan siswa dalam tahap merancang percobaan $\mathbf{7 6 , 8 5 \%}$ dengan kategori cukup, penulisan cara kerja $\mathbf{7 2 , 2 2 \%}$ dengan kategori cukup, penulisan hasil percobaan $\mathbf{8 8 , 8 9 \%}$ dengan kategori sangat baik, penulisan pembahasan $49,44 \%$ dengan kategori kurang sekali dan penulisan hasil percobaan $\mathbf{6 9 , 4 4 \%}$ dengan kategori cukup.

Secara keseluruhan kemampuan siswa menerapkan kerja ilmiah pada topik ciri-ciri makhluk hidup melalui pendekatan keterampilan proses sebesar $66,47 \%$ dengan kategori cukup. Sedangkan pada tahapan-tahapan kerja ilmiah tersebut yang meliputi penulisan rancangan percobaan, penulisan cara kerja, penulisan hasil percobaan, pembahasan dan kesimpulan kemampuan siswa bervariasi.

Kemampuan siswa pada tahapan penulisan rancangan percobaan $76,85 \%$ dengan kategori cukup, dalam tahapan ini siswa diminta untuk menggunakan keterampilan mengamati, karena rancangan percobaan ini selain menuliskan tujuan juga ada penulisan alat dan bahan yang tentu saja harus teliti dalam menuliskan alat dan bahan apa saja yang digunakan dalam percobaan yang akan dilakukan. 
Pada tahapan penulisan cara kerja kemampuan siswa 72,22\% dengan kategori cukup. Kelemahan siswa ini dikarenakan tidak beruntunnya tahapan cara kerja yang ditulis dan siswa masih kurang dalam penulisan kalimat yang baik dan benar. Pada tahapan penulisan hasil percobaan kemampuan siswa $88,89 \%$ dengan kategori sangat baik. Hal ini disebabkan karena percobaan yang dilakukan berhasil dan tidak harus menuliskan hasil percobaan tersebut dalam kalimat yang panjang. Pada tahapan penulisan pembahasan kemampuan siswa 49,44\% dengan kategori kurang sekali karena kebanyakan siswa tidak menyebutkan alasan dari hasil percobaan yang diperolehnya. Pada tahapan penulisan hasil kesimpulan kemampuan siswa $69,44 \%$ dengan kategori cukup, karena kebanyakan siswa telah menuliskan kesimpulan sesuai dengan tujuan dari percobaan yang dilakukan.

Proses pembelajaran dengan menerapkan kerja ilmiah pada topik ciri-ciri makhluk hidup melalui pendekatan keterampilan proses berjalan dengan lancar. Hal ini dapat dilihat dari aktivitas siswa yang terlihat aktif. Walaupun proses pembelajaran ini masih sangat asing bagi siswa, namun siswa dapat belajar dengan tenang baik pada pertemuan pertama maupun pada pertemuan kedua.

Proses pembelajaran pada pertemuan pertama dilaksanakan di laboratorium IPA SMP Negeri 14 Pontianak. Sekitar 30 menit sebelumnya, peneliti yang bertindak sebagai guru mempersiapkan alat dan bahan yang akan digunakan. Hal-hal yang harus dipersiapkan adalah 2 ekor ikan dalam toples, tanaman putri malu, 2 pot tanaman bunga (yang dibungkus dengan plastik dan tidak dibungkus dengan plastik), kaca, Mobil mainan dan gambar pertumbuhan manusia. Semua yang disebutkan tadi ditempatkan pada meja masing-masing kelompok (11 kelompok). Selain itu, peneliti juga membagikan LKS (Lembar Kerja Siswa) yang dilengkapi dengan lembar tahapan kerja ilmiah serta Lembar Penilaian Diri (Self Assesment). Selain itu peneliti juga menuliskan sebuah tabel di papan tulis. Tabel inilah yang nantinya akan membantu siswa memahami topik yang akan diajarkan. Dalam pertemuan pertama ini peneliti yang bertindak sebagai guru tidak memberikan atau menjelaskan topik ciri-ciri makhluk hidup secara langsung, namun siswa dituntun untuk menemukan sendiri dan memahami topik tersebut melalui LKS (Lembar Kerja Siswa) yang telah disediakan.

Pengarahan dan pertanyaan yang telah disajikan di dalam LKS (Lembar Kerja Siswa) mereka selesaikan dalam kelompok masing-masing. Komentar guru tentang cara kerja kelompok yang mesti dilakukan ternyata mendapat perhatian. Beberapa anggota kelompok berupaya untuk mengarahkan temannya supaya ikut mengerjakan LKS (Lembar Kerja Siswa) yang telah disediakan. Selain itu, ada kelompok yang mengalami kesulitan, 
bertanya kepada guru. Akan tetapi guru meminta kelompok yang lain untuk menanggapi pertanyaan tersebut. Sehingga terjalin interaksi antara kelompok yang satu dengan kelompok yang lain.

Pada akhir pertemuan, Lembar Kerja Siswa (LKS) tersebut dibahas. Setelah terkumpul semua, peneliti yang bertindak sebagai guru akan mengambil salah satu Lembar Kerja Siswa (LKS) secara acak dan mempersilahkan kepada anggota dari kelompok tersebut untuk membacakan hasil kerja kelompoknya. Hal ini dilakukan agar semua siswa tidak penasaran dan bertanya-tanya tentang jawaban yang benar dari Lembar kerja Siswa (LKS) tersebut. Kelompok yang terpilih tadi bertindak sebagai penyaji sedangkan kelompok yang lainnya berpartisipasi untuk bertanya atau menyanggah. Dengan demikian antara siswa yang satu dengan siswa yang lainnya akan berkomunikasi mencermati suatu masalah dalam forum yang formal. Pada hasil observasi hanya empat orang yang terlihat aktif bertanya, menjawab atau memberikan sanggahan. Sedangkan siswa yang lainnya lebih banyak membandingkan hasil kerja yang dimilikinya dengan hasil kerja kelompok penyaji. Hal ini kemungkinan dikarenakan siswa belum terbiasa berkomunikasi dalam forum yang formal.

Harapan yang ingin dicapai dalam pengajaran dengan menerapkan kerja ilmiah melalui pendekatan keterampilan proses adalah selain jawaban yang benar, siswa diminta untuk menuliskan tahapan kerja ilmiah yang telah dilakukan pada lembar yang disediakan (lembar tahapan kerja ilmiah) secara terperinci mulai dari rancangan percobaan (tujuan, alat dan bahan), cara kerja, hasil percobaan, pembahasan dan kesimpulan. Jadi, skor yang diperoleh pada tiap-tiap kelompok akan berbeda karena kecermatan dalam menuliskan uraian jawaban antara kelompok yang satu dengan kelompok yang lainnya tidaklah sama.

Dalam kerja ilmiah salah satu unsur yang terpenting adalah sikap ilmiah. Untuk mengetahui dan mengukur sikap ilmiah, dapat dilihat dari lembar Penilaian Diri (Self Assesment). Dari lembar Penilaian Diri (Self Assesment) dapat dilihat sikap ilmiah yang dimiliki oleh seluruh siswa. Sebagian besar siswa kelas VII B SMP Negeri 14 Pontianak bersikap jujur dan bertanggung jawab.

\section{DAFTAR PUSTAKA}

Arifin, Zainal. 1988. Evaluasi Instruksional. Remaja Rosdakarya: Bandung.

Arikunto, S. 1993. Dasar- Dasar Evaluasi Pendidikan (Cetakan Ke-10). Bumi Aksara: Yogyakarta. 
Arikunto, S. 1990. Prosedur Penelitian Suatu Pendekatan Praktek. Rineka Cipta: Jakarta.

Budikase. E dan Abdurrahman. 1993. Telaah Kurikulum IPA SMP 1. Depdikbud: Jakarta.

Danapriana, D dan Rony Setiawan. 2004. Pengantar Statistika. Graha Ilmu: Bekasi.

Depdiknas. 2006. Model Pengembangan Silabus Mata Pelajaran Dan Rencana Pelaksanaan Pembelajaran IPA Terpadu. Balitbang Depdiknas: Jakarta.

Nugroho. G.W., 2007. Penerapan Pembagian Dengan Menjumlahkan Kembali Sebagai Alternatif Meningkatkan Kemampuan Pembagian Bilangan Pada Siswa SD. Skripsi, Pontianak: FKIP UNTAN.

Haryati, M. 2006. Sistem Penilaian Berbasis Kompetensi. Gaung Persada Press: Jakarta.

Herawati, S. 2000. Kapita Selekta Pembelajaran Biologi. Pusat Penerbitan Universitas terbuka: Jakarta.

Indrawati. 2000. Keterampilan Proses Sains: Tinjauan Kritis Dari Teori Ke Praktis. Depdikbud: Bandung.

Nawawi, H. 1987. Metode Penelitian Bidang Sosial. Gadjah Mada University Press: Yogyakarta.

Nazir, M. 1993. Metode Penelitian. Ghalia Indonesia: Jakarta.

Pratiwi, 2004. Buku Penuntun Biologi SMP 1. Erlangga: Jakarta.

Prawironegoro, P. 1985. Evaluasi Hasil Belajar Khusus Analisis Soal Untuk Bidang Studi Matematika. Fortuna: Jakarta.

Purwanto, M.N. 1991. Prinsip- Prinsip dan Teknik Evaluasi Pengajaran. P.T. Remaja Rosdakarya: Bandung.

Semiawan, C. 1986. Pendekatan Keterampilan Proses. P.T. Gramedia: Jakarta.

Soetardjo. 1998. Proses Belajar Mengajar Dengan Metode Pendekatan Keterampilan Proses. SIC: Surabaya..

Sudjana. 2000. Metode Statistika. Tarsito: Bandung. 